\title{
STUDENTS LEISURE TIME AS A DETERMINANT OF THEIR PHYSICAL ACTIVITY AT UNIVERSITIES OF THE EU VISEGRAD GROUP COUNTRIES
}

\section{CZAS WOLNY STUDENTÓW CZYNNIKIEM WARUNKUJACYM AKTYWNOŚĆ FIZYCZNĄ NA PRZYKŁADZIE UCZELNI Z PAŃSTW WYSZEHRADZKICH}

\author{
Pongrác Ács ${ }^{1(A, B, D, E, G)}$, Barbara Bergier ${ }^{2(A, B, C, D, E, F)}$, Józef Bergier ${ }^{2(A, B, D, G)}$, \\ Ewelina Niźnikowska $^{2(A, B, D)}$, Ján Junger ${ }^{3(A, B, D, G)}$, Ferdinand Salonna ${ }^{4(A, B, D)}$ \\ ${ }^{1}$ University of Pecs, Hungary \\ ${ }_{2}^{2}$ Pope John Paul II State School of Higher Education in Biała Podlaska, Poland \\ ${ }^{3}$ Pavol Jozef Šafárik University in Kosice, Institute of Physical Education and Sport, the Slovak Republic \\ ${ }^{4}$ Palacky University of Olomunec, the Czech Republic
}

\author{
Authors' contribution \\ Wkład autorów: \\ A. Study design/planning \\ zaplanowanie badań \\ B. Data collection/entry \\ zebranie danych \\ C. Data analysis/statistics \\ dane - analiza i statystyki \\ D. Data interpretation \\ interpretacja danych \\ E. Preparation of manuscript \\ przygotowanie artykułu \\ F. Literature analysis/search \\ wyszukiwanie i analiza literatury \\ G. Funds collection \\ zebranie funduszy
}

\begin{abstract}
Summary
Background. Studies on physical activity are vital for those students destined to become the future elite in the Visegrad countries. This issue is of particular concern because most studies undertaken from various countries have, in this respect, demonstrated significant deficiencies. Study aims: to determine the link between students leisure time and their levels of physical activity according to gender.

Material and methods. Subjects were 2337 university students consisting of 1169 females and 1068 males from the Czech Republic, Slovakia, Poland and Hungary studying a variety of disciplines. The long version of the International Physical Activity Questionnaire (IPAQ) was used as a standardised measure for the study.

Results. Male students were found to have significantly more leisure time than females, with the highest levels observed in those studying the humanities, somewhat lower levels for the medical sciences whilst the lowest were for the technical sciences. The greater the amount of leisure time, the more significant was the impact found on levels of physical activity. Male students with sufficient leisure time demonstrated the highest levels of physical activity. However, no such relation was found in women where, in contrast, the highest levels of physical activity were found in those having too little leisure time.

Conclusions. The differences observed between genders in their links with leisure time and levels of physical activity should be taken into account when the teaching of physical activities are designed/devised for student studies.
\end{abstract}

Keywords: physical activity, IPAQ, leisure time, male/female students

\section{Streszczenie}

Wprowadzenie. Badania aktywności fizycznej studentów jako przyszłych elit każdego kraju mają szczególne znaczenie. Ranga tego problemu jest szczególnie ważna, gdyż większość badań $w$ różnych krajach pokazuje ich niezadowalający poziom. Celem pracy jest poszukiwanie związku czasu wolnego posiadanego przez studentów z uwzględnieniem płci z ich aktywnością fizyczną.

Materiał i metody. Materiał badawczy stanowili studenci wyższych uczelni z Czech, Słowacji, Polski i Węgier w liczbie 2. 237 osób z różnych kierunków studiów w tym 1.169 kobiet i 1.068 mężczyzn. Do badań wykorzystano Międzynarodowy Kwestionariusz Aktywności Fizycznej (IPAQ) w wersji długiej.

Wyniki. Wykazano istotnie większą ilość czasu wolnego wśród studiujących mężczyzn $\mathrm{w}$ odniesieniu do kobiet. Najwięcej czasu wolnego zadeklarowali studenci nauk humanistycznych, nieco mniej medycznych, a najmniej technicznych.

Większa ilość czasu wolnego wśród ogółu studentów ma istotny związek z ich całkowitą aktywnością fizyczną.

Studiujących mężczyzn o wystarczającej ilości czasu wolnego cechował najwyższy poziom całkowitej aktywności fizycznej. Takiego związku nie stwierdzono wśród kobiet, wręcz odwrotnie najwyższy poziom całkowitej aktywności fizycznej uzyskały studentki posiadające zbyt mało czasu wolnego.

Wnioski. Wykazane różnice miedzy studiującymi kobietami i mężczyznami w relacji ich czasu wolnego i poziomu aktywności fizycznej należy uwzględnić w procesie dydaktycznym zajęć ruchowych w trakcie studiów.

Słowa kluczowe: aktywność fizyczna, IPAQ, czas wolny, studenci, studentki
Tables: 7

References: 32

Submitted: 20.10 .2016

Accepted: 11.11 .2016

Acs P, Bergier B, Bergier J, Niznikowska E, Junger J, Salonna F. Students leisure time as a determinant of their physical activity at universities of the EU Visegrad Group countries. Health Problems of Civilization. 2016; 10(4): 31-41. doi: 10.5114/hpc.2016.63569.

Address for correspondence / Adres korespondencyjny: Pongrác Ács, University of Pécs, Faculty of Health Sciences, Pécs, Hungary, H-7621 Pécs, Vörösmarty u. 4, e-mail: pongrac.acs@etk.pte.hu, phone: 003672535980

Copyright: @ 2016 Pope John Paul II State School of Higher Education in Biała Podlaska, Pongrác Acs, Barbara Bergier, Józef Bergier, Ewelina Niźnikowska, Jan Junger, Ferdinand Salonna. This is an Open Access journal, all articles are distributed under the terms of the Creative Commons Attribution-NonCommercial-ShareAlike 4.0 International (CC BY-NC-SA 4.0) License (http://creativecommons.org/licenses/by-nc-sa/4.0/), allowing third parties to copy and redistribute the material in any medium or format and to remix, transform, and build upon the material, provided the original work is properly cited and states its license. 


\section{Introduction}

Studies on levels of physical activity in modern societies reflects a growing concern for public health. In the European societies of today, sedentary lifestyles are a common feature arising from progress made in the development of modern life. Serious threats to human health and mortality are now posed by the increasing reliance on cars as a means of transport; as well as in communication by spending more time at the computer or through watching television [1]. The health outcomes from performing physical activity depend on several important determinants that include systematic participation and through tailoring a regimen of physical activity to individual needs in terms of intensity and quantitative/qualitative aspects. In accordance with expert guidelines, physical activity is a fundamental determinant of human health, as has been stressed by the World Health Organization [2].

Studying physical activity in students is vital, because they will be representing the future elite from which are then shaped social patterns of personal health behaviour. The levels of physical activity in students are continuously surveyed by national monitoring $[3,4,5,6,7,8,9,10,11]$.

In this respect, it is instructive that reports published on this subject should be mentioned from different European countries as follows: Ukraine [12], Belgium [13], Germany [14], Czech Republic [15], Portugal [16], Bulgaria [17], Estonia [18], Visegrad countries of Europe [19] along with those from other continents: the United States [20], Turkey [21], Malaysia [22], Colombia [23], Iraq and Hungary [24] and Peru [25]. It is vital that the determinants of physical activity are identified through performing research. Our study aims are therefore to seek for the links between leisure time and taking part in physical activity according to gender.

\section{Materials and methods}

Study subjects consisted of 2237 university students from the Czech Republic, Slovakia, Hungary and Poland recruited in 2015, of whom 1169 were women and 1068 men. Of these, 29.6\% studied the humanities, 32.8\% medical science disciplines and $37.6 \%$ technical ones, (Table 1). The long version of the International Physical Activity Questionnaire (IPAQ) was used as the study tool, which allowed physical activity to be assessed within different areas of human activity ie. at work, whilst in-transit, in the home, recreation and in sport. The questionnaire was supplemented by some additional questions devised in-house.

Table 1. Subject characteristics

\begin{tabular}{|c|c|c|}
\hline \multicolumn{3}{|c|}{ Gender } \\
\hline Women & & Men \\
\hline $\begin{array}{c}1169 \\
(52.3 \%)\end{array}$ & & $\begin{array}{c}1068 \\
(47.7 \%) \\
\end{array}$ \\
\hline \multicolumn{3}{|c|}{ Self assessment of leisure time } \\
\hline None & Too little & Sufficient \\
\hline $\begin{array}{c}136 \\
(6.1 \%)\end{array}$ & $\begin{array}{c}1021 \\
(45.6 \%)\end{array}$ & $\begin{array}{c}1080 \\
(48.3 \%)\end{array}$ \\
\hline \multicolumn{3}{|c|}{ Levels of physical activity } \\
\hline Low & Moderate & High \\
\hline $\begin{array}{c}202 \\
(9.0 \%)\end{array}$ & $\begin{array}{c}911 \\
(40.7 \%)\end{array}$ & $\begin{array}{c}1124 \\
(50.3 \%)\end{array}$ \\
\hline \multicolumn{3}{|c|}{ Fields of study } \\
\hline The humanities & Medical science disciplines & Technical science disciplines \\
\hline $\begin{array}{c}662 \\
(29.6 \%)\end{array}$ & $\begin{array}{c}733 \\
(32.8 \%)\end{array}$ & $\begin{array}{c}842 \\
(37.6 \%)\end{array}$ \\
\hline
\end{tabular}

Sufficient amounts of leisure time were declared by $48.3 \%$ respondents, too little by $45.6 \%$ and a complete lack by $6.1 \%$. Slightly more than half the students (50.3\%) declared high levels of physical activity, $40.7 \%$ moderate, and $9.0 \%$ as low.

Statistical analyses were performed using STATISTICA V.10 software. The Chi-squared test was used to determine statistical significance for qualitative variables, whilst the non-parametric Kruskal-Wallis and Mann-Whitney U tests were used on quantitative variables. A p $\leq 0.05$ level was considered statistically significant. 


\section{Results}

As a means for determining the study objectives, the relationships between leisure time and undertaking physical activity were analyses according to gender. Moreover, this analyses also included the study disciplines chosen by the student subjects.

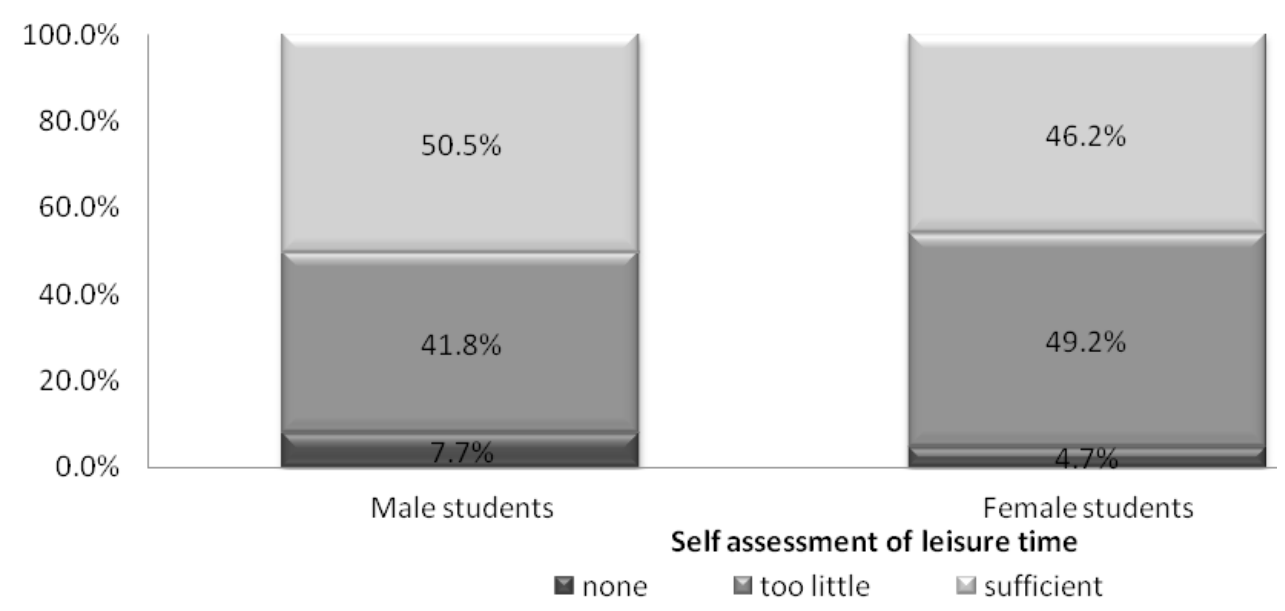

Pearson Chi-squared: $\chi 2=16.75 ; p=0.0002^{*}$

* significant difference at $\mathrm{P}<0.05$

Figure 1. Self-assessment of students' leisure time by gender

Statistically significant differences in leisure time were observed between genders $(p=0.0002)$. The highest proportion of students having sufficiently long leisure times were males (50.2\%) whilst for females, the highest proportions were found in those with too little free time (49.2\%). A complete lack of leisure time was found slightly more often in male students (7.7\%) than females (4.7\%); Figure 1).

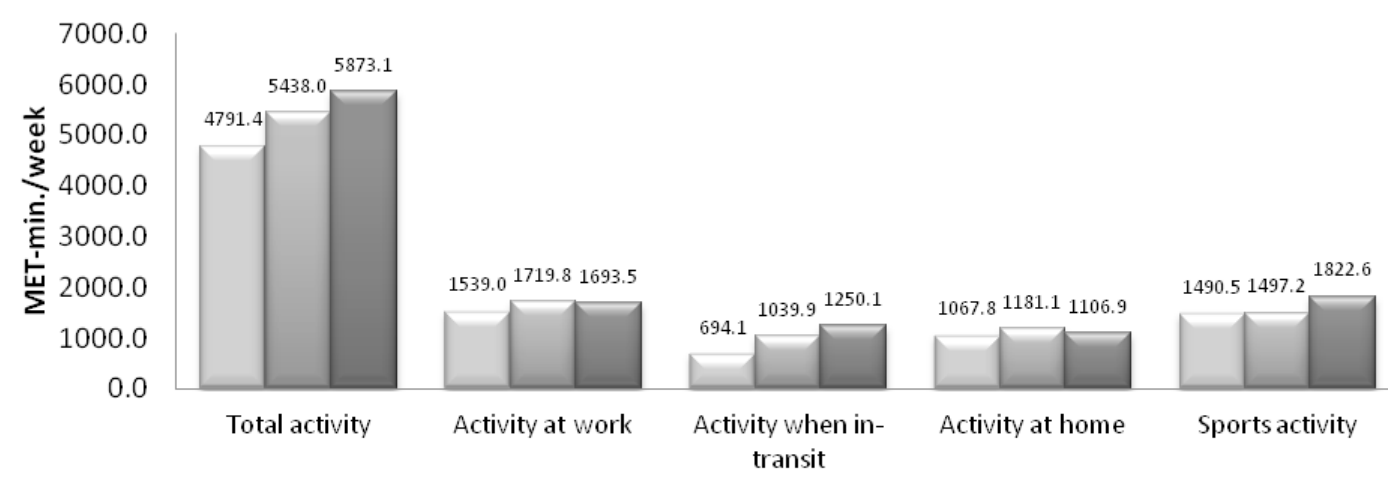

\section{Self-assessment of leisure time \\ $\triangle$ none $\square$ toolittle $\square$ sufficient}

Figure 2. A self-assessment of physical activity by male/female students according to location and their leisure time.

Whenever there is more leisure time, the total physical activity increased in all subjects. A similar finding is demonstrated whilst subjects undertook sports activities and when in-transit; Figure 2. 
Table 2. Different locations where physical activity takes place for male/female students when their leisure time is self-assessed.

\begin{tabular}{|c|c|c|c|}
\hline \multicolumn{3}{|c|}{ Kruskal-Wallis test } \\
\hline $\begin{array}{c}\text { Physical activity } \\
\text { location }\end{array}$ & $\mathbf{H}$ & $\mathbf{p}$ & Differences \\
\hline Total activity & $\mathbf{8 . 8 2}$ & $\mathbf{0 . 0 1 2 2} *$ & $\mathbf{1 - 2 . 3}$ ** \\
\hline Activity at work & 4.23 & 0.1204 & - \\
\hline Activity when in-transit & $\mathbf{2 2 . 5 8}$ & $\mathbf{0 . 0 0 0 1 *}$ & $\mathbf{1 - 2 . 3 ; 2 - 3 ^ { * * }}$ \\
\hline Activity at home & $\mathbf{6 . 9 4}$ & $\mathbf{0 . 0 3 1 0}$ & - \\
\hline Sports activity & 2.83 & 0.2427 & - \\
\hline
\end{tabular}

${ }^{*}$ - significant differences at $\mathrm{p}<0.05$

**- self assessment of leisure time between given limits where differences are statistically significant 1-None, 2-Too Little and 3-Insufficient.

The statistics demonstrate significant differences in total activity $(\mathrm{p}=0.0122)$ which were significantly pronounced for those not having any time for leisure. Likewise, as for total activity, statistically significant differences were found in physical activity when in-transit $(p=0.0001)$ in students without leisure time compared to those declaring sufficient leisure time. Significant differences in physical activity versus the amounts of leisure time were also observed at the home $(p=0.0310)$ but none were seen at work $(p=0.1204)$ nor in sport activities ( $\mathrm{p}=0.2427)$; Table 2 .

Table 3. Description statistics at the locations where physical activity takes place for male/female students when their leisure time is self-assessed

\begin{tabular}{|c|c|c|c|c|c|c|c|c|c|}
\hline \multirow{3}{*}{ Activity location } & \multicolumn{9}{|c|}{ Self assessment of leisure time } \\
\hline & \multicolumn{3}{|c|}{ None } & \multicolumn{3}{|c|}{ Too little } & \multicolumn{3}{|c|}{ Sufficient } \\
\hline & & SD & $\mathbf{V}$ & & SD & $\mathbf{V}$ & & SD & $\mathbf{V}$ \\
\hline Total activity & 4791.4 & 5539.7 & 115.6 & 5438.0 & 5062.2 & 93.1 & 5873.1 & 5586.9 & 95.1 \\
\hline Activity at work & 1539.0 & 2975.6 & 193.4 & 1719.8 & 2614.3 & 152.0 & 1693.5 & 2555.3 & 150.9 \\
\hline Activity when in-transit & 694.1 & 1004.7 & 144.7 & 1039.9 & 1476.2 & 142.0 & 1250.1 & 1655.3 & 132.4 \\
\hline Activity at home & 1067.8 & 1541.0 & 144.3 & 1181.1 & 1554.1 & 131.6 & 1106.9 & 1455.9 & 131.5 \\
\hline Sports activities & 1490.5 & 2167.5 & 145.4 & 1497.2 & 1830.4 & 122.3 & 1822.6 & 2252.2 & 123.6 \\
\hline
\end{tabular}

Subjects having no leisure time achieved a total physical activity level of 4791.4 MET-min/week, those with too little 5438.0 MET-min/week whilst those that were sufficient in this respect reached 5873.1 MET-min/ week; Table 3.

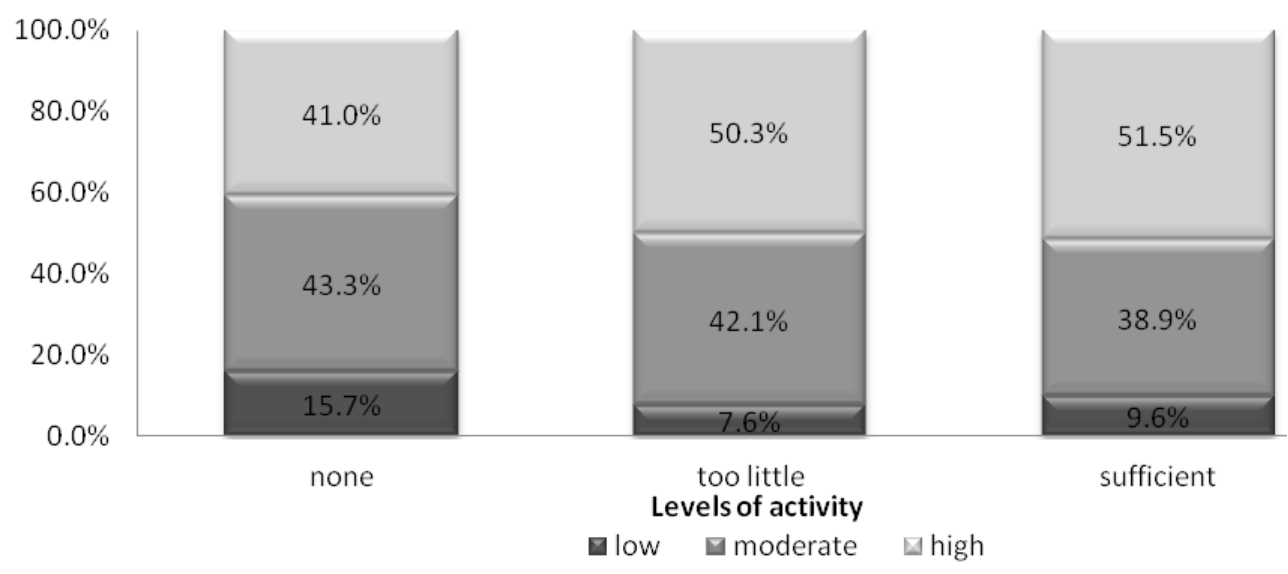

Pearson Chi-squared: $\chi 2=13.46 ; p=0.0092^{*}$

Figure 3. Physical activity levels of male/female students according to their self-assessment of leisure time

Levels of physical activity were significantly related to the amounts of leisure time $(p=0.0092)$. The majority of those with sufficient or too little leisure time demonstrated high levels of physical activity, whilst the majority of those declaring they had no leisure time undertook physical activity in $43.3 \%$ cases; Figure 3. 


\section{Male students}

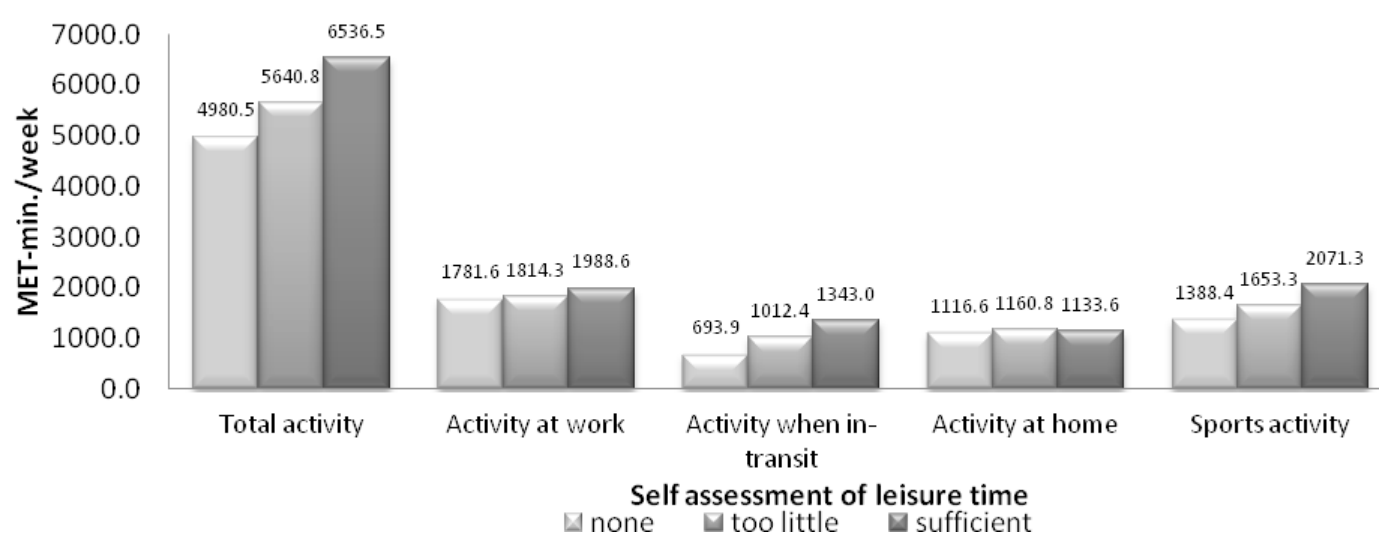

Figure 4. Different locations where physical activity takes place for male students when their leisure time is self-assessed

Table 4. Description statistics of the locations where physical activity takes place for male students when their leisure time is self-assessed

\begin{tabular}{|c|c|c|c|c|c|c|c|c|c|}
\hline \multirow{3}{*}{ Activity location } & \multicolumn{9}{|c|}{ Self assessment of leisure time } \\
\cline { 2 - 11 } & \multicolumn{3}{|c|}{ None } & \multicolumn{3}{c|}{ Too little } & \multicolumn{4}{c|}{ Sufficient } \\
\cline { 2 - 11 } & & SD & V & & SD & V & & SD & V \\
\hline Total activity & 4980.5 & 5986.3 & 120.2 & 5640.8 & 5352.4 & 94.9 & 6536.5 & 5967.5 & 91.3 \\
\hline Activity at work & 1781.6 & 3331.9 & 187.0 & 1814.3 & 2746.7 & 151.4 & 1988.6 & 2793.9 & 140.5 \\
\hline Activity when in-transit & 693.9 & 1019.2 & 146.9 & 1012.4 & 1469.2 & 145.1 & 1343.0 & 1783.9 & 132.8 \\
\hline Activity at home & 1116.6 & 1718.4 & 153.9 & 1160.8 & 1533.8 & 132.1 & 1133.6 & 1587.0 & 140.0 \\
\hline Sports activity & 1388.4 & 1630.9 & 117.5 & 1653.3 & 1981.6 & 119.9 & 2071.3 & 2399.0 & 115.8 \\
\hline
\end{tabular}

Highest levels of total physical activity were reported for those male students with sufficient time for leisure ie. 6536.5 MET-min./week. When leisure times decrease, then levels of physical activity were also observed to fall, as was clearly demonstrated in the case of total physical activity regarding in-transit activities and undertaking sport; Figure 3 and Table 4.

Table 5. Different locations where physical activity takes place for male students when their leisure time is self-assessed

\begin{tabular}{|c|c|c|c|}
\hline \multicolumn{2}{|c|}{ Kruskal-Wallis test } \\
\hline Physical activity location & H & $\mathbf{p}$ & Differences \\
\hline Total activity & $\mathbf{1 1 . 0 4}$ & $\mathbf{0 . 0 0 4 0}$ & $\mathbf{1 - 3}^{* *}$ \\
\hline Activity at work & 3.95 & 0.1384 & - \\
\hline Activity when in-transit & $\mathbf{1 7 . 4 1}$ & $\mathbf{0 . 0 0 0 2} *$ & $\mathbf{3 - 1}^{* *}$ \\
\hline Activity at home & 3.76 & 0.1527 & - \\
\hline Sports activity & 3.67 & 0.1599 & - \\
\hline
\end{tabular}

*- significant differences at $\mathrm{p}<0.05$

**- self assessment of leisure time between given limits where differences are statistically significant 1-None, 2-Too Little and 3-Insufficient.

Leisure time was found to significantly affect total physical activity $(p=0.004)$ as well as those physical activities performed when in-transit $(\mathrm{p}=0.0002)$. In the case of the former, significant differences were observed between students not having any of this leisure time and those where such times were sufficient. In the latter case (ie. physical activity when in- transit), significant differences were observed in those having sufficient leisure time who undertook high levels of physical activity as compared to the other two categories (ie. moderate and low physical activity); Table 5. 


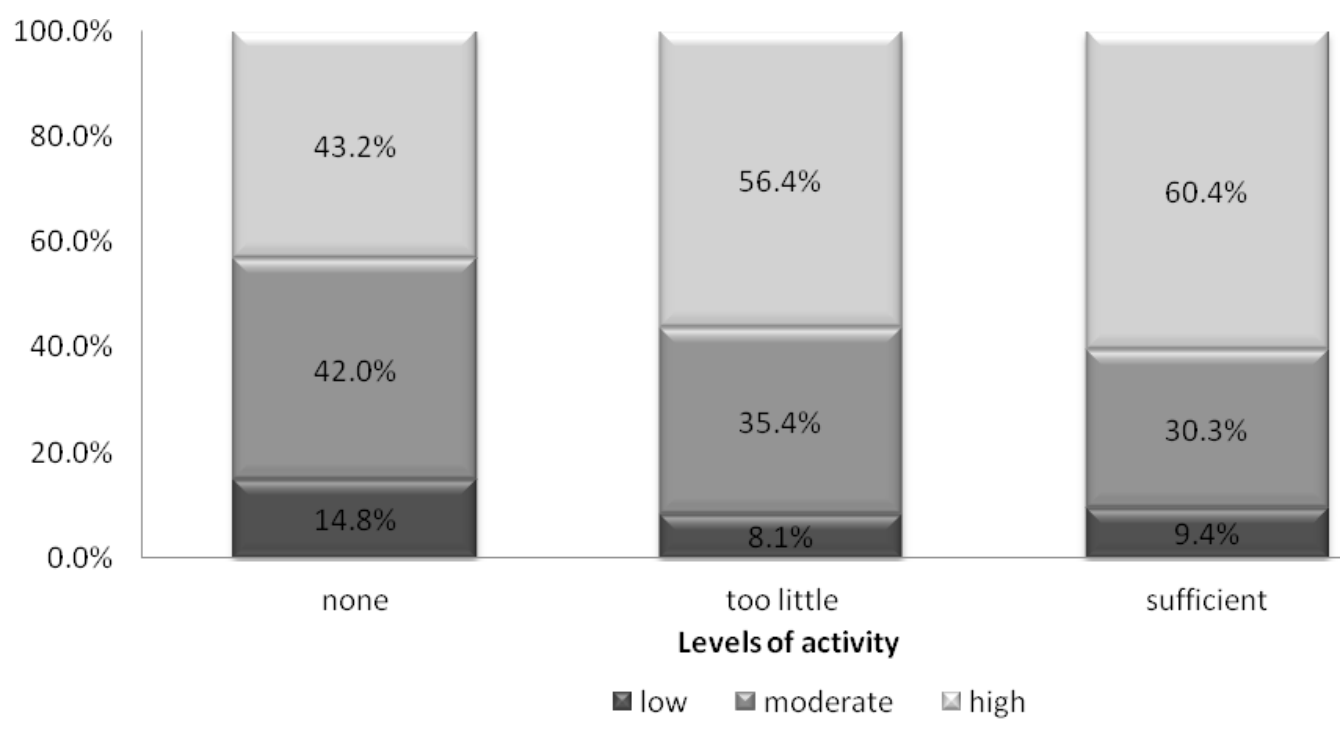

Pearson Chi-squared: $\chi 2=10.96 ; p=0.0270^{*}$

*- significant differences at $\mathrm{p}<0.05$

Figure 5. Physical activity levels of male students according to self-assessment of their leisure time

Significant differences in physical activity were found according to the amount leisure time possessed $(p=0.0270)$. Students with high levels of activity tended to have the most leisure time $(60.4 \%)$, whilst physical activity decreased with decreasing leisure time; Figure 5.

\section{Female students}

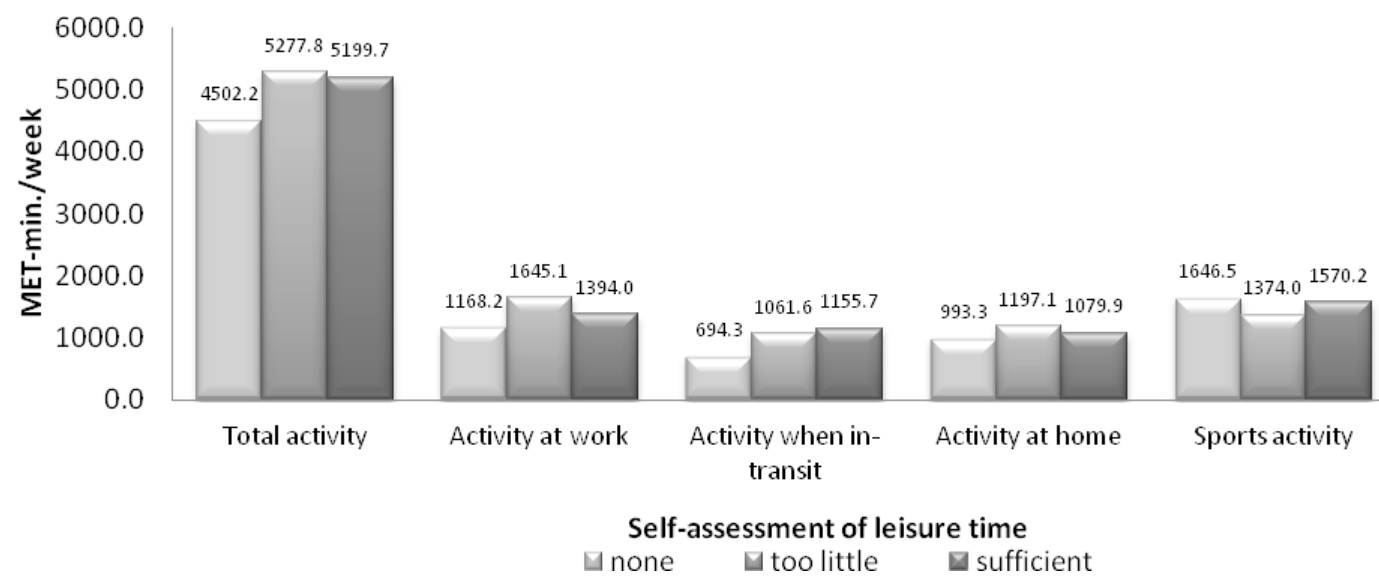

Figure 6. Different locations where physical activity takes place for female students when their leisure time is self-assessed

Table 6. Description statistics of the locations where physical activity takes place for female students when their leisure time is self-assessed

\begin{tabular}{|c|c|c|c|c|c|c|c|c|c|}
\hline \multirow{2}{*}{ Activity location } & \multicolumn{4}{|c|}{ Self assessment of leisure time } \\
\cline { 2 - 11 } & \multicolumn{3}{|c|}{ None } & \multicolumn{3}{c|}{ Too little } & \multicolumn{3}{c|}{ Sufficient } \\
\cline { 2 - 11 } & & SD & V & & SD & V & & SD & V \\
\hline Total activity & 4502.2 & 4818.6 & 107.0 & 5277.8 & 4819.6 & 91.3 & 5199.7 & 5089.8 & 97.9 \\
\hline Activity at work & 1168.2 & 2309.7 & 197.7 & 1645.1 & 2504.7 & 152.3 & 1394.0 & 2251.2 & 161.5 \\
\hline Activity in- transit & 694.3 & 991.8 & 142.8 & 1061.6 & 1482.7 & 139.7 & 1155.7 & 1509.6 & 130.6 \\
\hline Activity at home & 993.3 & 1233.5 & 124.2 & 1197.1 & 1571.1 & 131.2 & 1079.9 & 1310.3 & 121.3 \\
\hline Sports activity & 1646.5 & 2807.8 & 170.5 & 1374.0 & 1693.2 & 123.2 & 1570.2 & 2064.6 & 131.5 \\
\hline
\end{tabular}


For female students, the highest level of total physical activity was observed in those with too little leisure time (5277.8 MET-min/week) and in those with sufficient leisure time (5199.7 MET-min/week). At all locations (except sports activity), the lowest levels of activity were observed in students not having any leisure time. In contrast for sports activities, those ladies not having any leisure time undertook the highest levels of physical activity (1646.5 MET-min./week); Figure 6 and Table 6.

Table 7. Different locations where physical activity takes place for female students when their leisure time is self-assessed

\begin{tabular}{|c|c|c|c|}
\hline \multicolumn{2}{|c|}{ Kruskal-Wallis test } \\
\hline Physical activity location & H & p & Differences \\
\hline Total activity & 3.27 & 0.1945 & - \\
\hline Activity at work & 3.05 & 0.2173 & - \\
\hline Activity when in-transit & $\mathbf{6 . 4 7}$ & $\mathbf{0 . 0 3 9 5 *}$ & - \\
\hline Activity at home & 2.64 & 0.2666 & - \\
\hline Sporting activity & 0.25 & 0.8834 & - \\
\hline
\end{tabular}

- significant differences at $\mathrm{p}<0.05$

The levels of ladies' physical activity according to leisure time demonstrated that only the activity performed when in-transit differed significantly to the other places of activity $(p=0.0395)$, with differences between the others being insignificant; Table 7.

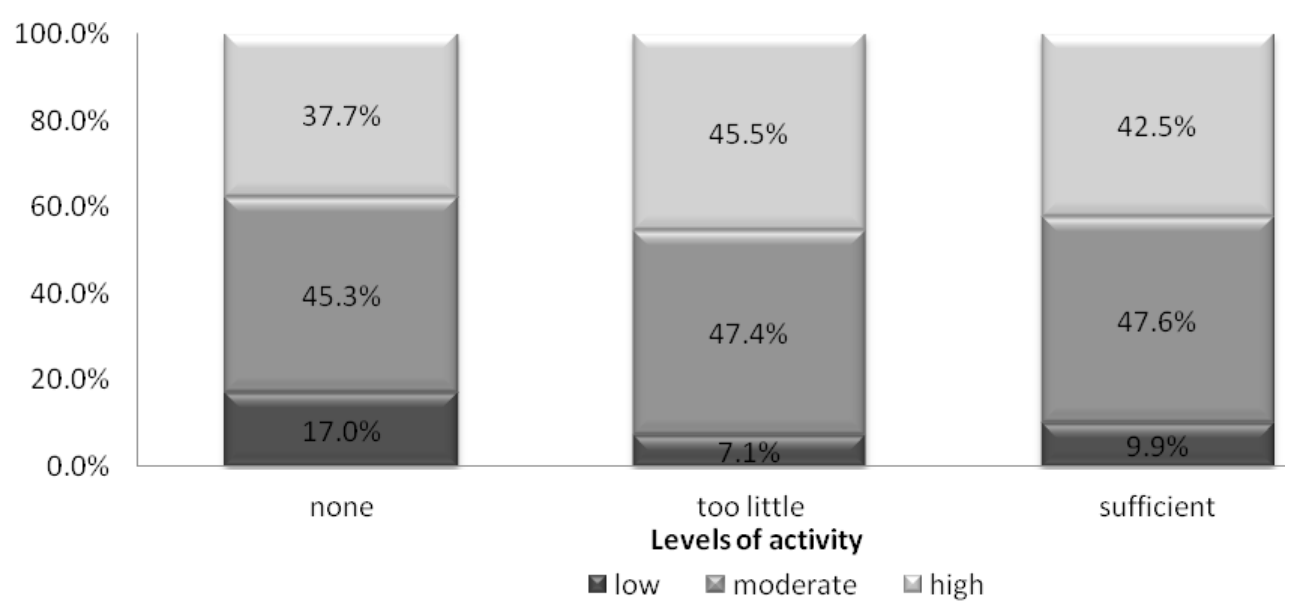

Pearson Chi-squared: $\chi 2=7.50 ; p=0.1116$

Figure 7. Physical activity levels of female students according to self-assessment of their leisure time

Regardless of leisure time, most subjects undertook moderate levels of physical activity. Low levels of physical activity were most commonly found in women not having any leisure time (17.0\%). There were no significant links observed between the amount of leisure time with levels of physical activity in female students; Figure 7. 


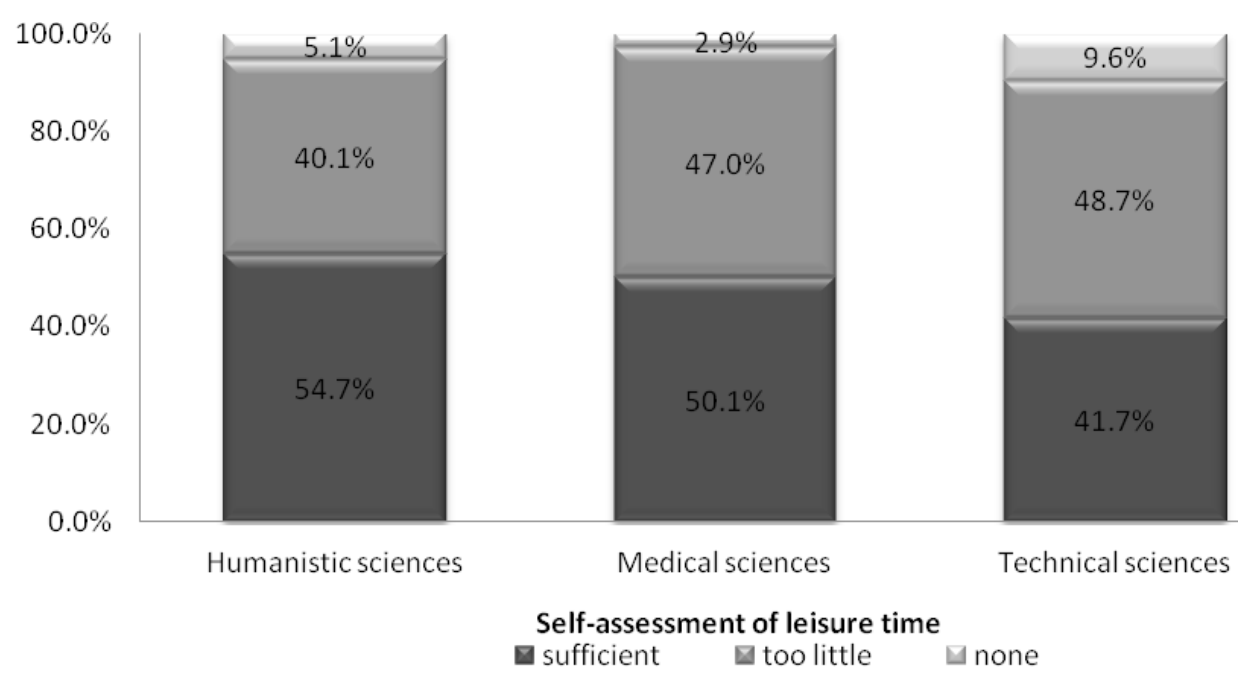

Pearson Chi-squared: $\chi 2=50.16 ; p<0.0001^{*}$

*- significant differences at $\mathrm{p}<0.05$

Figure 8. Chosen study disciplines by male and female students according to self-assessment of their leisure time

A significant association was however found between the chosen discipline of study and the amount of leisure time $(\mathrm{p}<0.0001)$. The greatest amount of student leisure time was found in the following fields: humanities (54.7\%) and medical sciences (50.1\%) but lowest in the technical sciences (41.7\%); Figure 8.

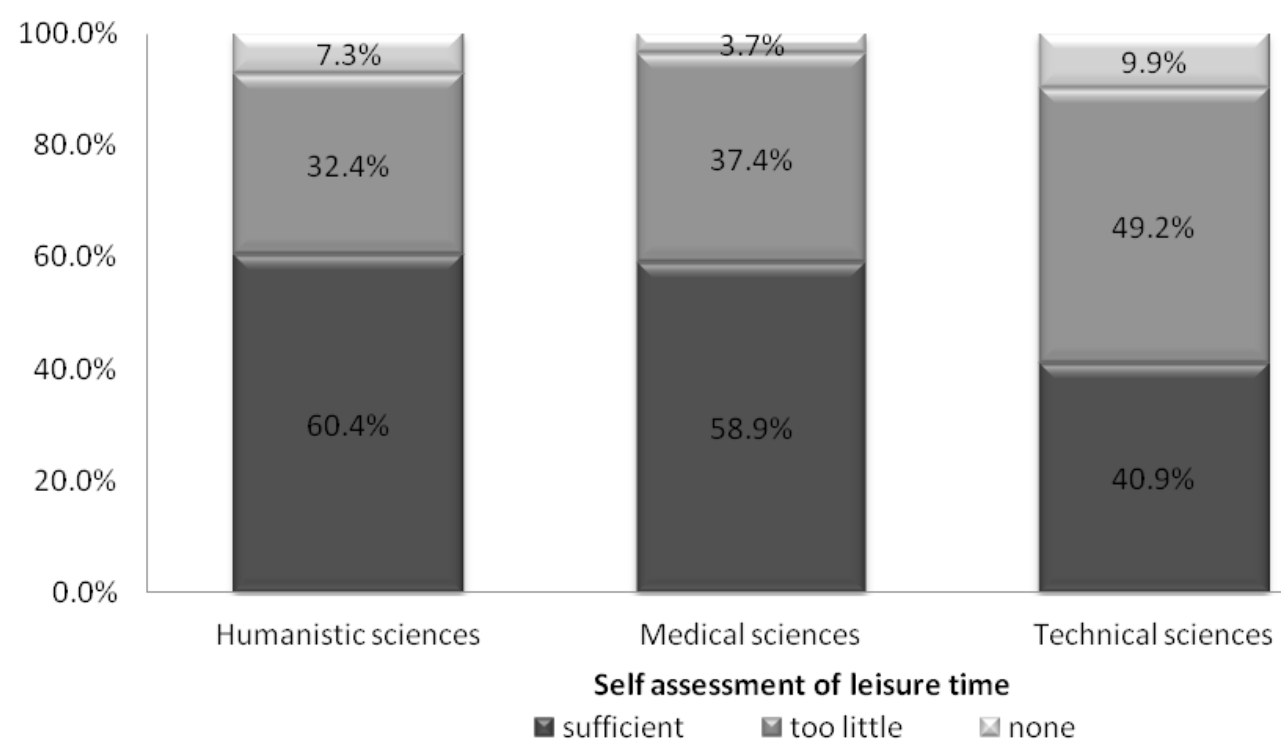

Pearson Chi-squared: $\chi 2=41.40 ; p<0.0001^{*}$

*-significant differences at $\mathrm{p}<0.05$

Figure 9. Chosen study disciplines by male students according to self-assessment of their leisure time

The majority of students studying the humanities and medical sciences had sufficient leisure time, respectively $60.4 \%$ and $58.9 \%$, whilst most of those studying technical sciences had too little; $49.2 \%$. Significant differences were found in the amount of leisure time depending on the study disciplines chosen; $p<0.0001$, Figure 9. 


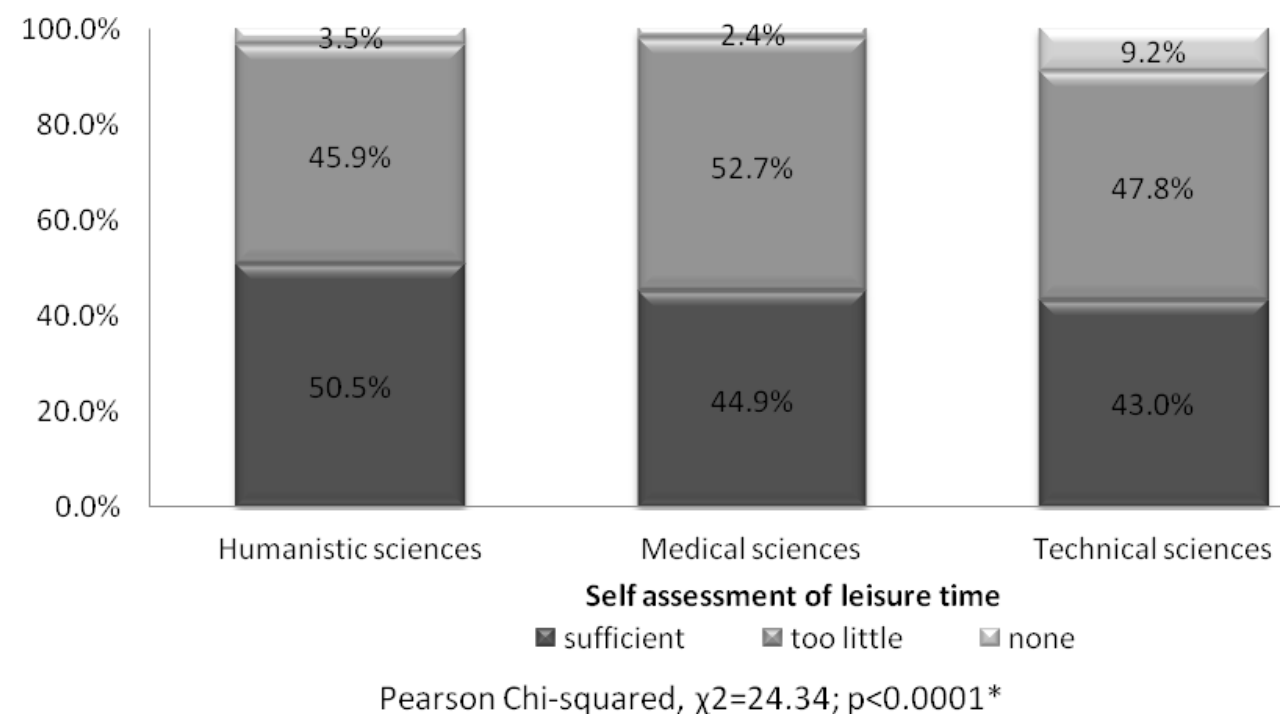

*-significant differences at $\mathrm{p}<0.05$

Figure 10. Chosen study disciplines by female students according to self-assessment of their leisure time.

The study results for female students were similar to males. Female students of the humanities possessed the longest leisure time (50.5\%) whilst those studying technical sciences had the shortest, of whom $9.2 \%$ said they had none at all. The type of discipline studied had a significant effect on the amount of leisure time; $\mathrm{p}<0.0001$, Figure 10.

\section{Discussion}

Publications dealing with the determinants of physical activity for students most frequently indicate those of gender, place of origin or material conditions. Leisure time is rarely ever mentioned in Polish studies on this topic as being a determinant of physical activity $(26,27,11,28,29)$. Despite studying levels of physical activity during leisure time, no study has actually investigated their inter-relationship $(8,30,31,17,18)$.

Our work has demonstrated that male students possess a significantly greater amount of leisure time than females, which has indeed been confirmed by other studies $(11,28)$, but not observed in the studies of Laszek (27). A possible reason that female students have less leisure time is due to their more time-consuming daily schedule of course work. The significantly longer leisure time seen in students studying the humanities, compared to the medical and technical sciences, may reflect that more time is required for studying the latter two disciplines.

Having longer leisure times is related to students showing the highest levels of physical activity in total, and including sports; however, contrasting outcomes were found when students' gender is considered, where this conclusion was true for male students but not for females. Female students having no leisure time or too little, conversely demonstrated the highest levels of physical activity. This may have arisen from women's greater awareness of the role that physical activity plays in adopting a healthy lifestyle.

\section{Conclusions}

1. Significant differences were observed in leisure time between the genders. Half of all students possessed sufficient free time, however half of the female students possessed to little.

2. Overall, the majority of leisure time was related to higher levels of total physical activity in male and female students when taken together. Similar results were observed for physical activity when in-transit and for sports. Significantly lower and non-beneficial levels of total activity and in-transit activity were observed in students with too little leisure time compared to those who had sufficient.

3. A significant relationship (correlation) was also found between levels of physical activity (high, moderate, low) and leisure time. Subjects with sufficient and too little leisure time, in the main demonstrated high levels of physical activity. For those students not having any leisure time, the highest proportion demonstrated moderate levels of physical activity.

4. Male students with enough leisure time attained the highest levels of total physical activity as well as for work, in-transit and sports activities. 
5. Female students having too little leisure time reached the highest levels of total physical activity and activities at work and at home. Those not having any leisure time demonstrated the highest levels of activity in sport but the lowest in its other areas.

6. Female students showed mostly moderate levels of physical activity regardless of leisure time; there was no significant relationship found between levels of physical activity and their leisure time.

7. A significant relationship between the disciplines studied and the amount of leisure time was found. Students of the humanities had the most leisure time, slightly less so for medical science students and the least for those studying the technical sciences.

\section{Acknowledgements}

Research was conducted in the framework of the project "Physical and recreational activity and eating habits of the youth from the V4 countries", co-financed from the funds of the Visegrad Fund.

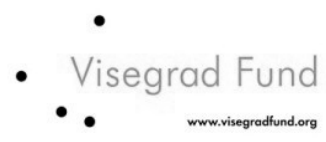

\section{References:}

1. Skorupska S, Łapiak-Pasiorowska E. Niska aktywność fizyczna. In: Kuch M, Janiszewski M, Mamcarz A. Rehabilitacja kardiologiczna. Warszawa: Oficyna Wydawnicza Medical Education; 2014. p. 184-186 (in Polish).

2. World Health Organization. Global status report on noncommunicable diseases 2014. WHO Genewa; 2014.

3. Kostencka A, Drabik J. Aktywność fizyczna studentów a ich wskaźniki masy ciała. Antropomotoryka. 2007; 40: 33-39 (in Polish).

4. Miązek U. Aktywność fizyczna w stylu życia studentek krakowskich uczelni. Wychowanie Fizyczne i Zdrowotne, 2005; 3: 12-19 (in Polish).

5. Adach J. Preferowane formy aktywności ruchowej studentów PWSZ w Sulechowie. In: Nałęcka D, Bytniewski M, editors, Teoria i praktyka rekreacji ruchowej. Biała Podlaska: Państwowa Wyższa Szkoła Zawodowa w Białej Podlaskiej; 2007. p. 214-220.

6. Garbaciak W, Mynarski W, Czapla K, Rozpara M. Wydolność tlenowa studentów o zróżnicowanej aktywności fizycznej. In: Mynarski W, editor. Teoretyczne i empiryczne zagadnienia rekreacji i turystyki. Katowice: AWF; 2007. p. 306-322 (in Polish).

7. Jach K, Chlebicka E. Zastosowanie wskaźnika PAI do oceny aktywności fizycznej w okresie zimowymi letnim. In: Szczepanowska E, Sokołowski M, editors. Aktywność fizyczna i odżywianie się, jako uwarunkowania promocji zdrowia. Poznań: Wielkopolska Wyższa Szkoła Turystyki i Zarządzania w Poznaniu; 2008. p. $97-104$ (in Polish).

8. Palacz J. Rekreacja ruchowa studentów wychowania fizycznego w czasie wolnym. In: Kubińska Z, Nałęcka D, editors.Rekreacja ruchowa w edukacji i promocji zdrowia. Biała Podlaska: Państwowa Wyższa Szkoła Zawodowa w Białej Podlaskiej; 2009. p. 168-177 (in Polish).

9. Sokołowski M. Międzynarodowy Kwestionariusz Aktywności Fizycznej (IPAQ) jako miernik oceny aktywności fizycznej studentów Akademii Wychowania Fizycznego. In: Szczepanowska E, Sokołowski M, editors. Aktywność fizyczna i odżywianie się, jako uwarunkowania promocji zdrowia. Poznań: Wielkopolska Wyższa Szkoła Turystyki i Zarządzania w Poznaniu; 2008. p. 113-123 (in Polish).

10. Biernat E. Aktywność fizyczna mieszkańców Warszawy. Na przykładzie wybranych grup zawodowych. Warszawa: Szkoła Główna Handlowa; 2011 (in Polish).

11. Bergier B, Niźnikowska E, Stępień E, Szepeluk A, Bergier J. Aktywność fizyczna studentów a ich czas wolny i samoocena sprawności fizycznej. Antropomotoryka. 2013; 64:41-47 (in Polish).

12. Bergier J, Bergier B, Tsos A. Physical activity and eating habits among female students from Ukraine. Health Problems of Civilization. 2015; 9(2): 5-12.

13. Deliens T, Deforche B, Bourdeaudhuij ID, Clarys P. Determinants of physical activity and sedentary behaviour in University students: A qualitative study using Focus group discussions. BMC Public Health. 2015; 15: 201. DOI: $10.1186 / \mathrm{s} 12889-015-1553-4$.

14. Dichl K, Hilger J. Physical activity and the transition from school to University: a cross-sectional survey among University students in Germany. Sci Sports 2016 http://dx.doi.org /10.1016/j. scispo. 2016.04.012. 
15. Kvintova J, Sigmund M. Physical activity, body composition and health assessment in current female university students with active and inactive lifestyles. Journal of Physical Education and Sport (IPES). 2016; 16 Suppl. Issue (1): 627-632.

16. Clemente FM, Nikolaidis PT, Martins FML, Mendes RS. Physical activity patterns in university students: Do they follow the public health guidelines? PLOS ONE. 2016; 11 (3): e0152516.doi:10.1371/journal. pone.0152516.

17. Ignatov G. Physical activity and sports in leisure time of students from the faculty for preschool and primary school education at Sofia university "st. kliment ohridski" - Bulgaria (Preliminary communication). Activities in Physical Education and Sport. 2016; 6(1): 29-34.

18. Lusmägi P, Einasto M, Eve-Liis Roosmaa E-L. Leisure-time Physical Activity Among Different Social Groups of Estonia: Results of the National Physical Activity Survey, PhysicalCulture and Sport. Studies and Research. DOI: 10.1515/pcssr-2016-0004 Vol. LXIX. 2016; 43-52.

19. Bergier J, Bergier B, Niźnikowska E, Junger J, Ács P, Frömel K, Szepeluk A. The diversity of the place of residence of students and their level of physical activity. Central European Journal of Sport Sciences and Medicine. 2016; 13(1): 123-132.

20. Ayc M, Chang WS, Amran N, Pathak R. Correlation between physical activity and memory functioning among university students. Internationa Journal of Pharmacology and Toxicology Science. 2013; 3(2): 1-8.

21. Müftüler M, Ince ML. Use of trans-contextual model-based physical activity course in developing leisure-time physical activity behavior of university students. Perceptual Mot Skills. 2015;121(1): 31-55.

22. Rajappan R, Selvaganapathy K, Liew L. Physical activity level among university students: A cross sectional survey. Int. J. Physiother Res. 2015; 3(6): 1336-43.

23. Puello FG, Beltran YH, Molina RT. Levels of physical activity among Colombian university students. Revista Medica de Chile. 2015; 143(11): 1411-8.

24. Mirzafian H. Perceived cosntraints to physical activity and sport: A cross-cultural study between Iranian and Hungarian university students. World Leisure Journal. 2016; 58(3): 193-206.

25. Ocampo-Muscaro J, Silva-Salazar V, da Costa-Bullon D. Correlation between knowledge about the consequences of obesity and physical activity levels among university students. Medware. 2015; 2:15(11): e 6329. doi 10.5867/medvare. 2015.11.6329.

26. Prusik K, Zaporozhanov V, Görner K. Stan aktywności fizycznej w stylu życia studentów Akademii Wychowania Fizycznego i Sportu w Gdańsku. Problemy Wychowania Fizycznego i Sportu, 2009; 12: 229-233.

27. Łaszek M, Nowacka E, Gawron-Skarbek A, Szatko F. Negatywne wzorce zachowań zdrowotnych studentów. Część II. Aktywność ruchowa i nawyki żywieniowe. Probl. Hi. Epidemiol. 2011; 92(3): 461-465.

28. Bergier B, Stępień E, Niźnikowska E, Bergier J. Aktywność fizyczna kobiet i mężczyzn studiujących w Państwowej Szkole Wyższej w Białej Podlaskiej. Medycyna Ogólna i Nauki o Zdrowiu, 2014; 20(2): 166-170.

29. Niźnikowska E, Stępień E. Physical activity of the students form Universitities in Biala Podlaska in their free time according to the chosen faculties. Health Problems of Civilization, 2015; 9(2): 13-18.

30. Tomczak A. Aktywność fizyczna podejmowana w czasie wolnym przez żołnierzy zawodowych instytucji centralnych MON w świetle Międzynarodowego Kwestionariusza Aktywności Fizycznej (IPAQ). In: Kaiser A, Sokołowski M, editors. Środowisko społeczno-przyrodnicze a aktywność fizyczna człowieka. Poznań: Wielkopolska Wyższa Szkoła Turystyki i Zarządzania w Poznaniu; 2010. p. 369-382 (in Polish).

31. Bezerra J, Silva Lopes A, Firpo Del Duca G, Cordeiro Barbosa Filho V, Gomes de Barros M. Leisure-time physical activity and associated factors among adolescents of Pernambuco, Brazil: From 2006 to 2011, Mudanças na atividade física no lazer e fatores associados em adolescentes de Pernambuco, Brasil: de 2006 a 2011. Rev Bras Cineantropom Desempenho Hum. 2016; 18(1): 114-126.

32. Kubińska Z, Danielewicz J. Zróżnicowanie stylu życia studentów uczelni w Białej Podlaskiej z uwzględnieniem aktywności fizycznej. Antropomotoryka 2013, 23(63): 47-54. 